\title{
EVOLUTION IN CHEMOTHERAPY OF HUMAN AND ANIMAL HELMINTHIASES
}

\author{
(review)
}

\author{
M.Kh. Dzhafarov \\ Center for Scientific and Engineering Problems, \\ 11, Ulanskii per., Moscow, 101000 Russia; \\ Moscow State Academy of Veterinary Medicine and Biotechnology named K.I. Skryabin, \\ 23, ul. akademika Skryabina, Moscow, 109472 Russia, \\ e-mail:mxd123@mail.ru \\ Received April 24, 2013
}

\section{Su m mary}

The attention is focused on the main classes of anthelmintics. Mode of action of the anthelmintics and the anthelmintic resistance, and alternative methods for dehelminthization are discussed. A targeted search for new anthelmintic substances in the series of speculative parental hydrocarbons (benzene, indene, naphthalene, $1 \mathrm{H1}$-cyclopenta [a]-naphthalene and phenanthrene) is suggested to be prospective on the basis of variation in their structure from the fully unsaturated to saturated forms, including those containing heteroatoms $(\mathrm{N}, \mathrm{O}, \mathrm{S})$, various functional groups and substituents:

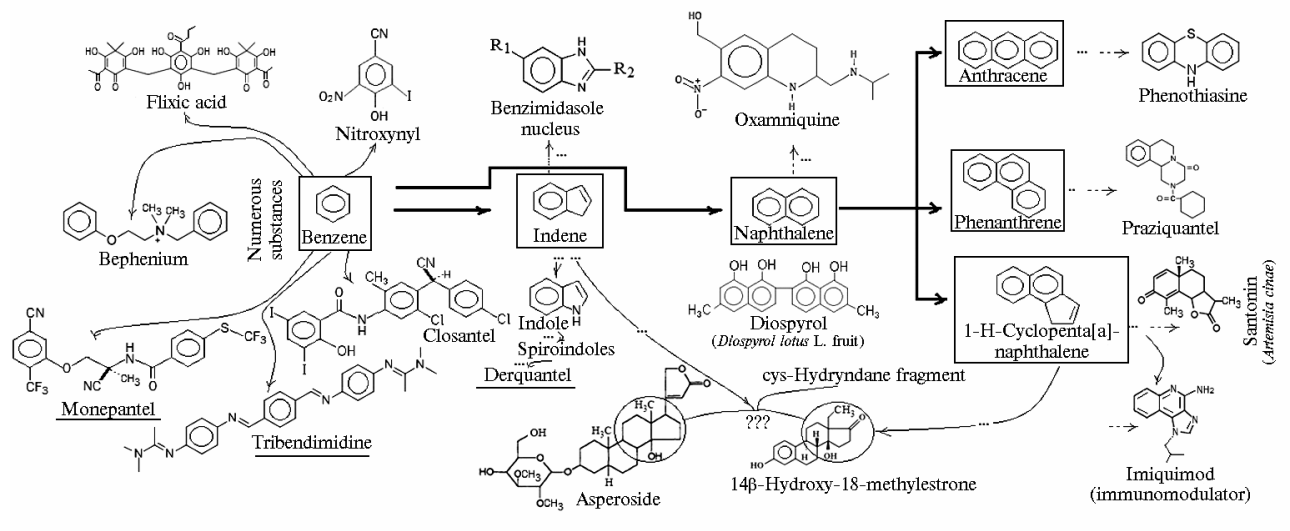

Keywords: animal and human helminthoses, chemotherapy and prophilaxis, anthelmintic substances, folk remedy, inorganic and organic anthelmintics, santonin, flixic acid, phenothiazine, pyrazine, benzimidazoles, imidazolthiazoles, tetrahydropyrimidines, avermectins and its analogs, gemacs, salicylanilides, nitazoxanide, emodepside, aminoacetonitril derivatives (AADs), monepantel, spiroindols, derquantel, tribendimidine, biological methods of the controls of helminthosis.

Helminthiases cause significant damage to the economy, including damage to human health and capacity to work (1-3), decline in meat, dairy and egg production, barrenness and mortality of livestock, loss in quality of skin and wool (4), as well as damage to plant industry (5), lumber, etc. Helminths often affect both companion animals and wild animals (6-8). One of the most effective and relatively cheap methods of helminth control is chemotherapy (9).

Today, hundreds of anthelmintics with various spectra of activity are available in the market. However, regarding active ingredients of these drugs (both mono- and multicomponent formulations), there are only few dozen highly effective and relatively safe substances of different chemical nature $(10,11)$.

Anthelmintic compounds may be of natural origin or products of chemical synthesis. Natural substances are mainly represented by secondary metabolites of bacteria, fungi, and plants, formulated in native or chemically modified form (12).

Folk remedies, inorganic and organic substances. Before chemotherapy, for thousands of years healers used various powders, decoctions, ointments, tinctures as remedies for treatment of diseases (13), including helminthiases (14); these folk remedies were prepared from minerals, fungi, plants, tissues, products of vital activity of animals (venoms of snakes and spiders, mothers milk) (15), and even whole animals (leeches, bees, etc.). Anthelmintics were originally called "vermifuges" (from Latin: vermus - worm, fugere - expulsion) (14).

A plenty of folk remedies had been established (16) and included in reference books of ancient and medieval philosophers and healers. For example, the ancient Egyptian papyrus Ebers (dated around $1550 \mathrm{BC}$ ) contains information on human schistosomiasis and helminths (14). Hippocrates in his writings (about $500 \mathrm{BC}$ ) described some parasitic worms and introduced the terms "helminthiases" and "ascariasis" (in Greek - respectively, a disease caused by worms and ascaris) (17). Galen (about 129-200 BC) was one of the founders of pharmacology; he suggested methods of preparation of tinctures and ointments (e.g. with plant extracts), so-called "Galen drugs", and he also introduced the concept of active ingredients (18). Avicenna in "The Canon of Medicine" (980-1037 BC) described malaria and many helminths such as Dracunculus (19). These guidebooks contain information about healing diseases caused by parasitic worms, such as using wormwood Artemisia cinae in ascariasis. This plant contains santonin, a natural compound with anthelmintic effect; this sesquiterpene lactone was first isolated in 1830 by German potheker Kahler and pharmacy student J.A. Alms from a raw plant material of Russian origin (20). It had been introduced into medical practice in 1838 (21) though its chemical structure was determined only in 1963 (22). Compounds with anthelmintic properties were isolated from many other plants (pomegranate, aspen, male fern, tansy, some species of chamomile, tobacco, pumpkin, garlic) $(18,23,24)$. Currently, rhizome extract of male fern (Dryopteris filix-mas) is a source for the drug Filixanum used in treatment of cestodiases (10). Structural formulas of some anthelmintic substances of plant origin are shown below: 

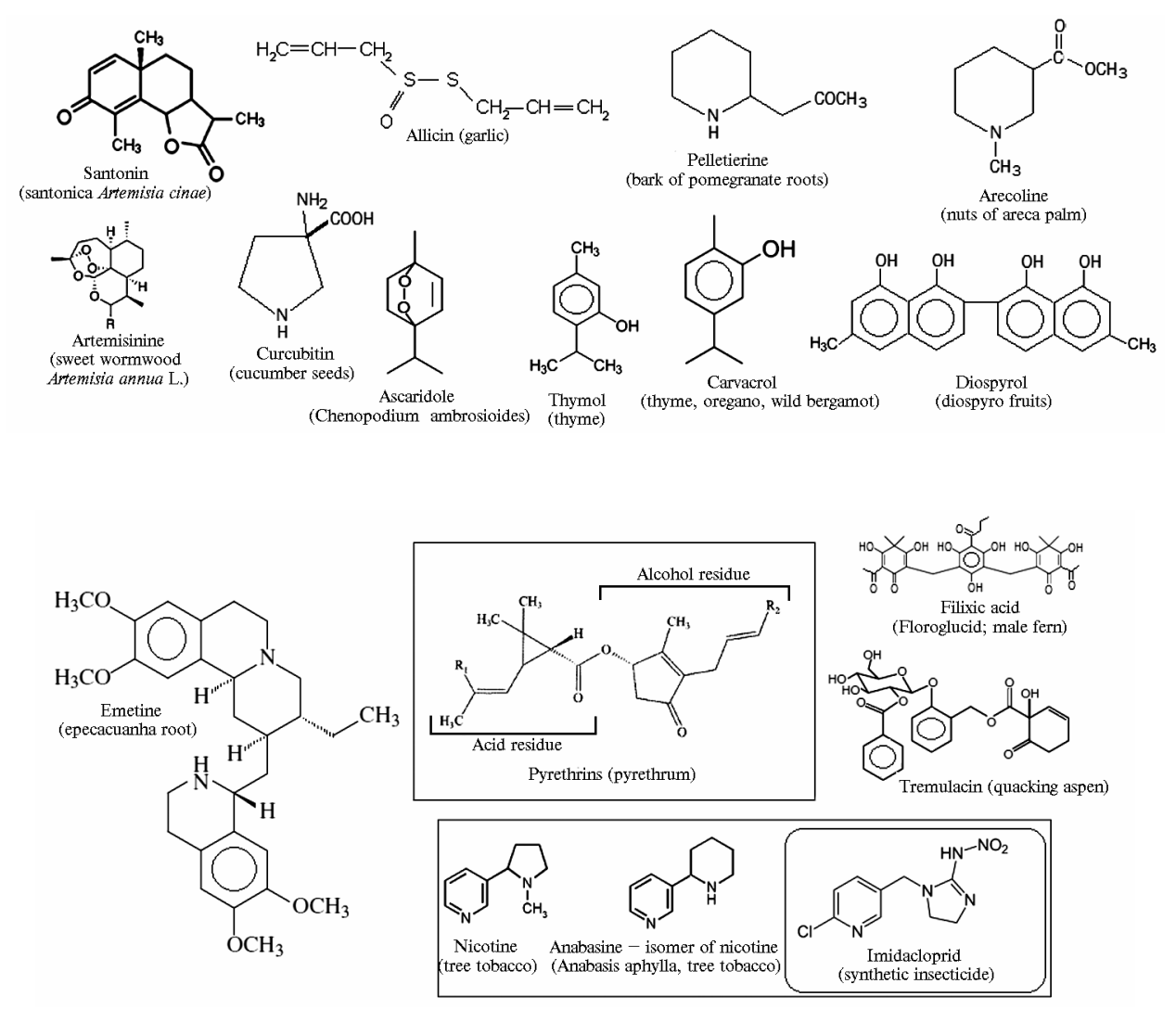

The idea of using chemical compounds in medication of animals and humans was proposed even by alchemists (IV-XVI century), in particular by iatrochemists (iatrochemistry, or medical chemistry, from Greek iatrós - doctor); they investigated and prepared remedies (XVI-XVIII centuries) from chemical compounds known at that time (25) - mostly derivatives of $\mathrm{Hg}, \mathrm{As}, \mathrm{Sb}, \mathrm{Cu}$, $\mathrm{Zn}, \mathrm{Fe}, \mathrm{S}$. One of these substances, Glauber's salt $\mathrm{Na}_{2} \mathrm{SO}_{4} * 10 \mathrm{H}_{2} \mathrm{O}$, is still used in some cases as laxative for expulsion of intestinal helminths (26).

Scientific basis of the chemotherapy of parasitic diseases (and helminthiases) started its development in XIX-XX centuries with establishment of the structural theory of organic and inorganic compounds (25). P. Ehrlich, Nobel Prize winner of 1908, upon the study of more than 600 arsenic compounds showed the possibility of direct synthesis of drugs capable to affect microorganisms; he proposed the term "chemotherapy". His research allowed obtaining the arsenic drug atoxil introduced into clinical practice in 1910 as medication against trypanosomiasis (27) along with the antisyphilitic drug salvarsan (28). Another chemical drug suramin - a derivative of carbonic acid amide (urea) - was introduced into clinical use in 1916 and, in some cases, is still prescribed against onchocerciasis and sleeping sickness trypanosomiasis (the use is limited due to high toxicity) (10).
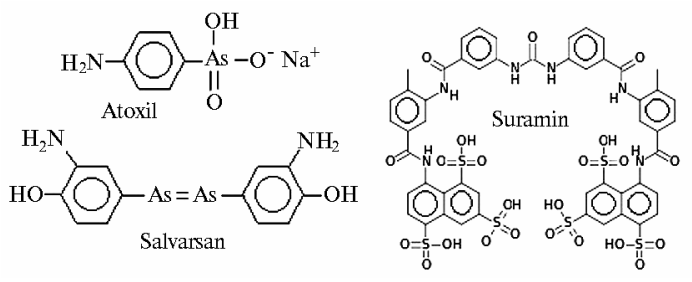

At the beginning of XX century, simple organochlorine compounds carbon tetrachloride $\mathrm{CCl}_{4}(1921)$ and hexachlorethane $\mathrm{C}_{2} \mathrm{Cl}_{6}$ (1928) were introduced as new anthelmintics against Fasciola hepatica (10). These toxic substances now are scarcely ever applied on mammals, but hexychol (chlorinated derivative of paraxylene, in clinical practice of the USSR since 1964) is still present in a current list of anthelmintics in some republics of the former Soviet Union and in China (effective against mature flukes) (29).

Before the middle of the XX century, despite the rapid increase in number of synthesized organic compounds there were widely used anthelmintics based on inorganic compounds of arsenic (As), tin ( $\mathrm{Sn}$ ), stibium ( $\mathrm{Sb}$ ), fluorine (F), hydrogen peroxide $\left(\mathrm{H}_{2} \mathrm{O}_{2}\right)$, sulfur (S ), oxygen $\left(\mathrm{O}_{2}\right)$, arsenates of metals - aluminum, divalent metals $(\mathrm{Ca}, \mathrm{Cu}, \mathrm{Zn}, \mathrm{Sn}), \mathrm{Fe}$ (bivalent and trivalent). For example, effective dose of Paris Green and calcium arsenate, $\mathrm{Ca}_{3}\left(\mathrm{AsO}_{4}\right)_{2}$ against mature and immature worms in lambs was 0,3-0,5 $\mathrm{g} /$ head (30), blue vitriol $\mathrm{CuSO}_{4} * 5 \mathrm{H}_{2} \mathrm{O}$ for buffalo calves $-112 \mathrm{mg} / \mathrm{kg}$ body weight (31). Nowadays, inorganic anthelmintics are not applied due to high toxicity and displacement by more effective organic substances such as albendazole, fenbendazole, praziquantel, and other agents effective against moniezia of ruminants and other parasitic diseases $(9,11)$. However, certain organometallic compounds (e.g., $\mathrm{As}^{3+}$-based sodium thioacetarsamid and melarsomin) are prescribed for dogs against heartworm (Dirofilaria immitis) (32). Here are structural formulas of some arsenic and stibium-containing anthelmintic substances: 


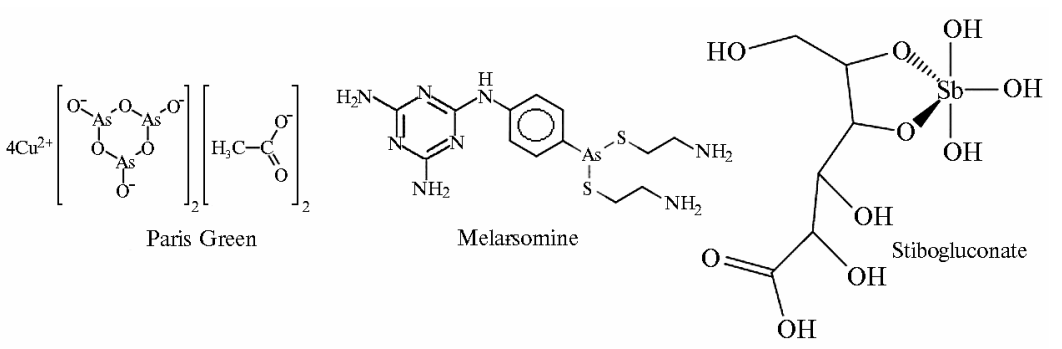

Chlorine, blue vitriol, hydrated lime still remain in practice of veterinarians, breeders, and health services as means for decontamination of water bodies, stalls, buildings, etc. It is being performed an exploration work aimed at creation of complex anthelmintic substances, such as pectinate of albendazole and copper (II) $(n=20-30, \mathrm{Mw}=17000-25000 \mathrm{Da})(33)$

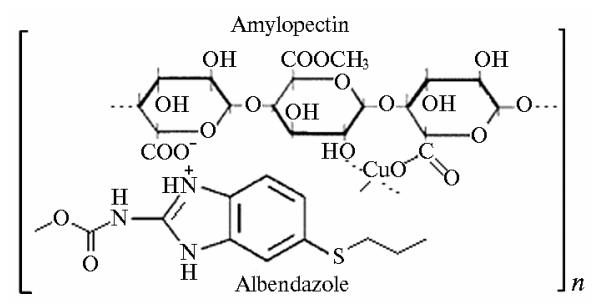

Modern chemotherapy of helminthiases. Phenothiazines and piperazines. The 1940-1950-ies gave a turning point to chemotherapy of helminth infections with introduction of synthetic organic compounds - phenothiazine (1940; methylene blue, the first representative of phenothiazines, was used as a fabric dye) (34) and piperazine (1953) (35) as anti-nematode agents:
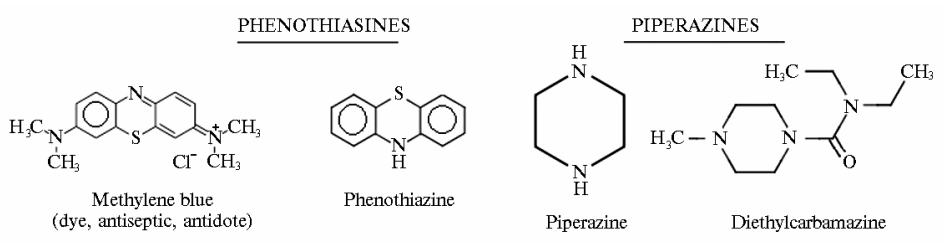

Veterinarians still prescribe piperazine and its salts (adipate, sulfate, phosphate) and phenothiazine in cases of ascariasis of fur animals, pigs, and poultry, diethylcarbamazine - against nematodes (toxocariasis, filariasis, etc.) (10).

Benzimidazoles and other N-containing anthelmintics. In 1960-ies, clinical practice obtained effective broad-spectrum anthelmintics - benzimidazoles (most abundant group), imidazolthiazoles, tetrahydropyrimidines effective against intestinal and nonintestinal nematodes and cestodes:

1. BENZIMIDAZOLES

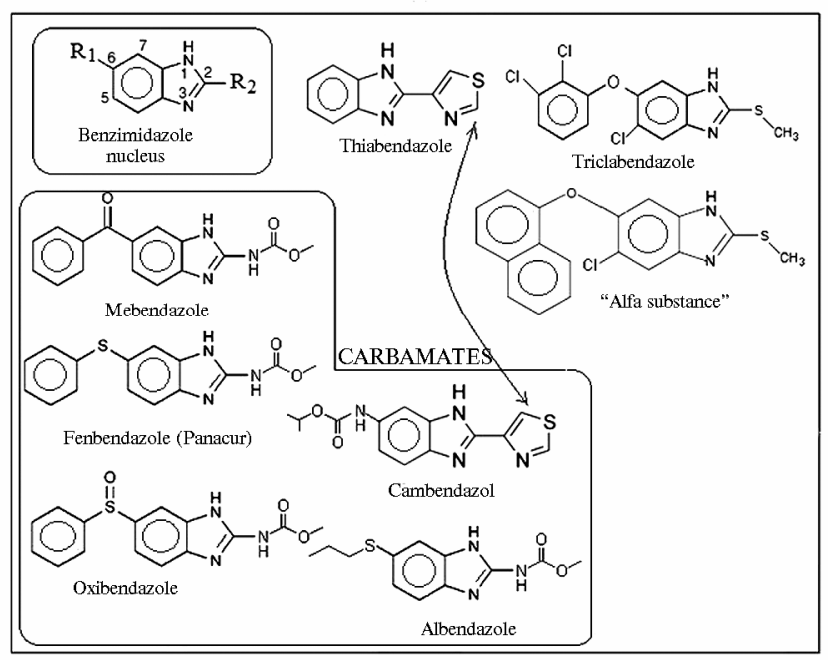

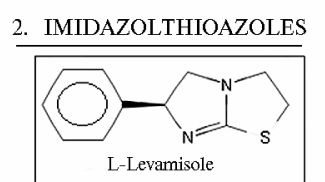

3. TETRAHYDROPIRIMIDINES

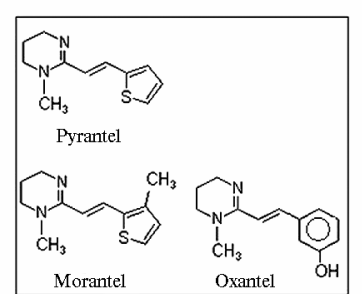

The first representatives of these anthelmintics were thiabendazole (1961), albendazole (since 1972 permitted for treatment of echinococcosis of animals and human) (36), levamisole (1966) (37), and pyrantel (1966) (38). Some of them are still applied (often in multicomponent formulations) (10).

In the 1970s, there appeared other nitrogen-containing heterocyclic substances. The most important of them were pyrazin isoquinolines such as praziquantel (biltricide, established 1977) used against cestodes and trematodes (39). Praziquantel has a good account and is still prescribed as schistosomicide for animals and human (9-11):

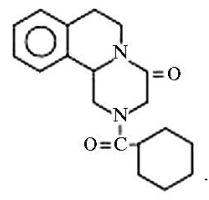


16-membered macrolides. The 1980s opened the era of natural avermectins (abamectin, doramectin) - products of soil bacteria Streptomyces avermitilis, and their semi-synthetic derivatives (ivermectin, selamectin, etc.) with wide spectrum of activity (against nematodes, insects, and mites) at very small doses ( 0.2-0.3 mg/kg) (Table 1) (40).

Milbemycines are a subgroup of 16-membered macrolides related to avermectins. They are produced by actinomycete $S$. hygroscopicus (ssp. aureolacrimosus) as a mixture of compounds whose structure shows the absence of disaccharide side chain at $\mathrm{C}(13)$ position and the presence of methyl (milbemycin A3), ethyl (milbemycin A4), isopropyl (milbemycin D), and sec-butyl (13deoxy-22,23- dihydroavermectin B1a) groups, as well as saturated 22,23-bond (similar to ivermectin) (1972) (41). Semisynthetic 5oximines of milbemycines A3 and A4 are used as pesticides (41). Milbemycin-related substances nemadectins were discovered in late 1980s; these products of $S$. hygroscopicus (ssp. noncyanogenus) contain hydroxyl group at $\mathrm{C}(23)$, unsaturated hydrocarbon radical on $\mathrm{C}(25)$ and, like milbemycines, the absence of disaccharide side chain at $\mathrm{C}(13)$. Nemadectin is used as raw material for production of moxidectin (active ingredient of the veterinary drug cydectin used for treatment and prevention of endoectoparazitic infections - common scab, dictyocauliasis, intestinal strongyloidiasis, lice, oestrosis, hypodermatosis) (41) $(*, * *$, and *** - position of allowable modifications in lactones; position R specifies a structure as avermectin, milbemycin, or nemadectin, and R, for which milbemycines differ from nemadectins)

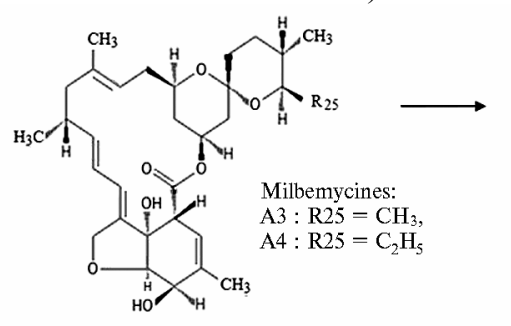

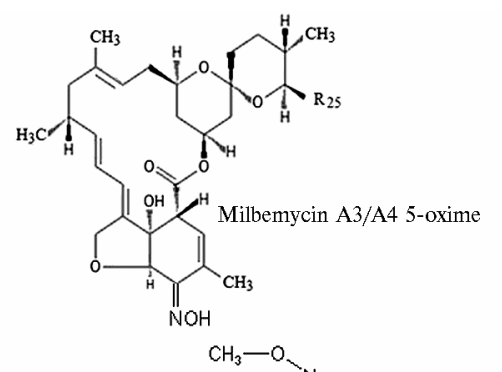

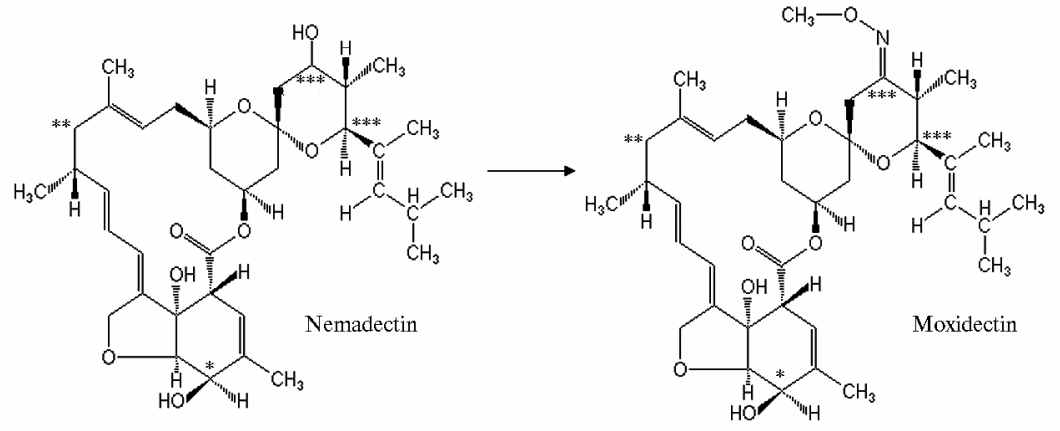

1. Structure of substances from the group of avermectin B1 and doramectin

\begin{tabular}{|c|c|c|c|c|}
\hline Substance & 1 & 2 & 3 & 4 \\
\hline $\begin{array}{l}\text { Avermectins B1: } \\
\mathrm{B}_{1 \mathrm{a}} \text { (basic product; } \mathrm{R} 25=\text { sec-Butyl) } \\
\mathrm{B}_{\mathrm{lb}} \text { (minor product; } \mathrm{R} 25=\text { iso-Propyl) }\end{array}$ & $\mathrm{R}(5), \mathrm{H}(5)$ & $\mathrm{R}\left(4^{\prime \prime}\right)$ & $\mathrm{R}(25)$ & $\mathrm{C}(22)-\mathrm{C}(23)$ \\
\hline Abamectin (native form) & $\mathrm{OH}, \mathrm{H}$ & $\mathrm{OH}$ & $\begin{array}{l}\text { Two homologs: } \\
\text { sec-Butyl, iso- } \\
\text { Propyl }\end{array}$ & Double bond \\
\hline Emamectin (semisynthetic) & $\mathrm{OH}, \mathrm{H}$ & $\stackrel{\mathrm{H}_{3} \mathrm{C}^{\prime}}{\mathrm{H}}$ & $\begin{array}{l}\text { Two homologs: } \\
\text { sec-Butyl, iso- } \\
\text { Propyl }\end{array}$ & Double bond \\
\hline Eprinomectin (semisynthetic) & $\mathrm{OH}, \mathrm{H}$ & $\mathrm{H}_{\mathrm{N}}^{\mathrm{H}} \mathrm{C}$ & $\begin{array}{l}\text { Two homologs: } \\
\text { sec-Butyl, iso- } \\
\text { Propyl }\end{array}$ & Double bond \\
\hline Ivermectin (semisynthetic) & $\mathrm{OH}, \mathrm{H}$ & $\mathrm{OH}$ & $\begin{array}{l}\text { Two homologs: } \\
\text { sec-Butyl, iso- } \\
\text { Propyl }\end{array}$ & Single bond \\
\hline Doramectin (native; in specific conditions) & $\mathrm{OH}, \mathrm{H}$ & $\mathrm{OH}$ & One homolog: & Double bond \\
\hline $\begin{array}{l}\text { Selamectin (4'-O-desoleandrozyl-5-desoxy-5-dehydro-5-oximin- } \\
\text { 22,23-dihydrodoramectin) - deglycolated semisynthetic analog of } \\
\text { doramectin }\end{array}$ & $\prod_{\mathrm{HO}^{-N}}^{\mathrm{N}}$ & $\begin{array}{l}\text { Missing residue of } \\
\text { one molecule of } \\
\text { oleandrose (dihy- } \\
\text { drolyzed disaccha- } \\
\text { ride 1",4'-glycoside } \\
\text { bond) }\end{array}$ & One homolog: & Single bond \\
\hline
\end{tabular}

Biological activity of avermectins. Along with anthelmintic activity, avermectins have many valuable properties that are in focus of research (47). Ivermectin blocks PAK1-dependent cell growth in benign and malignant tumors (neurofibromatosis type 
II, ovarian carcinoma, and others) through inactivation of p21-dependent protein kinase (PAK1) (48, 49). It was recently found that ivermectin inhibits replication of yellow fever virus (50) and sporogony of Plasmodium falciparum and Anopheles gambiae (51), as well as antituberculous effect of avermectins (52).

Salicylanilides and other anthelmintic substances. This important class of anthelmintics was discovered during investigation of biocidal action of phenolic compounds (phenols, bisphenols, thiophenols, etc.) used as anti-microbial and fungicidal agents (e.g. carbolic acid) (Lister J., 1867). These had been niclosamide (Hecht G. et al., 1960), tribromsalan (Boray J.C. et al., 1965), clioxanide (Boray J.C. et al., 1965), upon which later were developed more effective substances - oxyclozanide (Broome A.W. et al., 1966), closantel (Janssen M.A.C. et al., 1973), and rafoxanide (Mrozik H. et al., 1969) important for the control of distomiasis (53). Along with these basic classes of anthelmintics, there were developed numerous substances (10) of different chemical nature, such as hygromycin (aminoglycoside antibiotic and anthelmintic produced by bacteria Streptomyces hygroscopicus) (54), and organophosphorus substances (metrifonate, cythiolate, etc.) (10) of a limited use due to low efficiency or significant side effects (14).
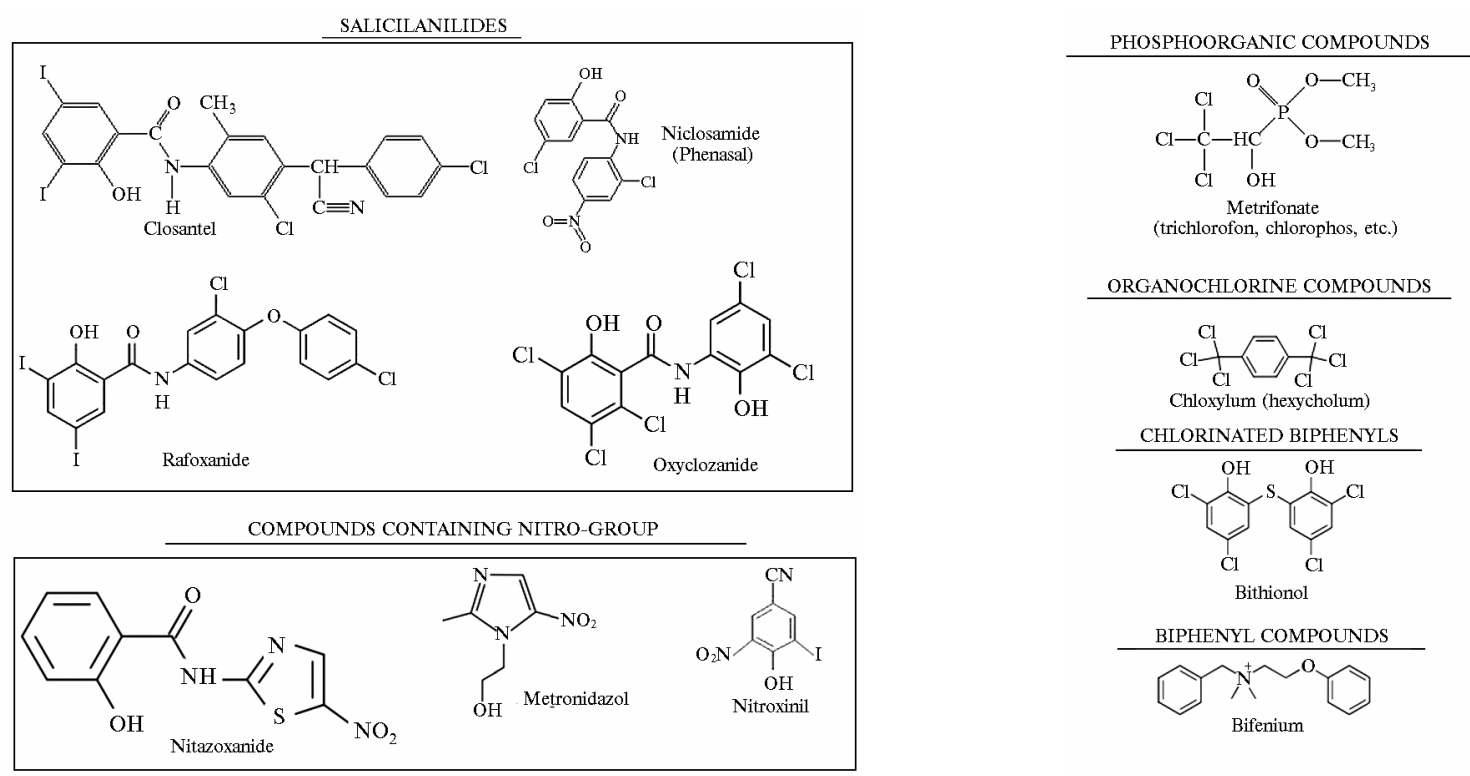

Molecular mechanisms of action. Presence of anthelmintic properties in a wide range of chemical substances is explainable - there is a great variety of hosts and worms that often develop drug resistance, along with some other factors. Anthelmintic drug introduced to a patient is being involved in two groups of processes that occur before the manifestation of a therapeutic effect. The first group of processes are physicochemical and chemical interactions with environmental factors ( $\mathrm{pH}$, temperature, enzymes, etc.) that affect the substance during its transfer to location of helminth in the host's body (Fig. 1) with corresponding biochemical and physiological consequences. The drug may undergo enzymatic and non-enzymatic changes - for example, dichlorvos in aqueous solution spontaneously converts to the more active substance that interacts with nicotinic acetylcholine receptor - nAChR (14) or nitazoxanide: plasma enzyme quickly ( $\sim$ min) modify it into active metabolites tizoxanide and glucuronide-tizoxanide that inhibit pyruvate: ferredoxin-oxidoreductase and thus violate the energy metabolism in helminths (55). 


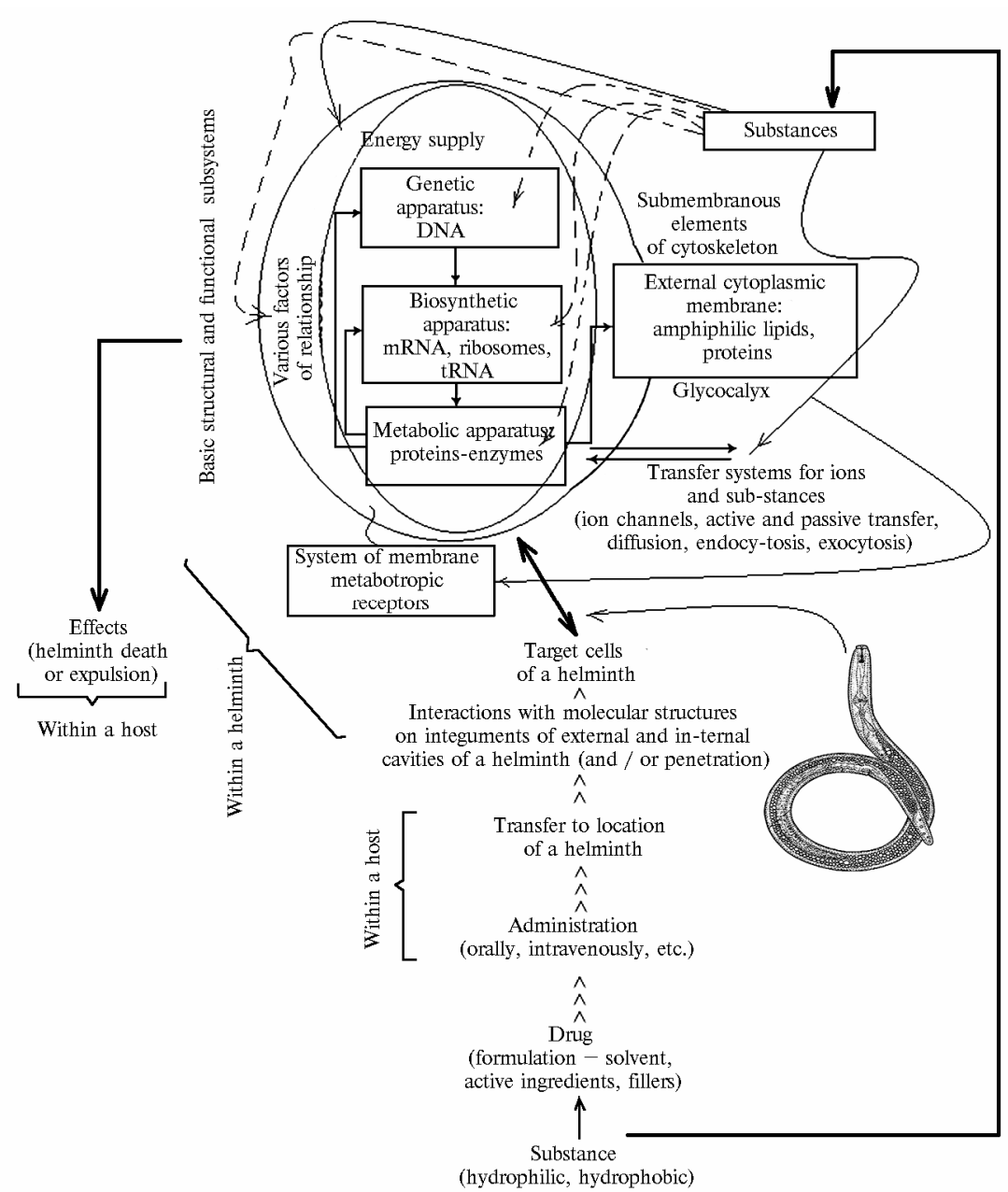

Fig. 1. Scheme of delivery of anthelmintic substance to helminth in a host's body and interaction with target cells

The second group of processes provides transfer of an anthelmintic to target cells through worm's external tissues (cuticle, tegument) or internal cavities (oral, pharyngeal, intestinal) and its interaction with these cells (Fig. 1).

Regarding interaction with target cells, anthelmintics segregate into drugs with quick action (2-4 hours; disturb functioning of ionotropic receptors) and delayed action (1-4 days; affect metabolic processes) (56) (Fig. 2). The quick-acting ones act as agonists (imidazolthiazoles, tetrahydropyrimidines, pyrazinisoquinolines, aminoacetonitrile derivatives, etc.) and antagonists (phenothiazine, spiroindoles) of $n$-AChRs, allosteric modulators of GABA $_{A}$-receptor (GABA - $\gamma$-aminobutyric acid) and glutamate-dependant chloride channels (GluCls) (16-membered macrolides - avermectins and milbemycines), agonists of GABA-ergic receptors (piperazine), activators of $\mathrm{Ca}^{2+}$ channel (praziquantel) and $\mathrm{Ca}^{2+}$-dependent $\mathrm{K}^{+}$-channel SLO-1 (emodepsid). Slow-acting ligands of $\beta$ tubulin (benzimidazoles) violate its polymerization and formation of microtubular apparatus, which leads to degenerative changes and other metabolic disorders in nematode's gut cells and cuticle. Others anthelmintics with delayed action - substances containing SHgroups (melarsomin); cholinesterase inhibitors such as carbamates, organophosphates (metrifonate), biphenyl compounds (bifenium, nitrosocanate, amoscanate); lipoxygenases and cyclic lipoxygenases (diethylcarbamazine - disturbs metabolism of arachidonic acid and inhibits formation of prostaglandins in a host, which causes constriction of its capillary bed and makes it impassible for microfilaria; also enhances phagocytosis of microfilaria by vascular wall, lymphocytes, and granulocytes; the action is possibly associated with inducible NO-synthase), chitinases (closantel - has a proton ionophore activity synergistic with inhibition of chitinase), pyruvate: ferredoxin-oxidoreductase (nitazoxanide) $(56,57)$. 


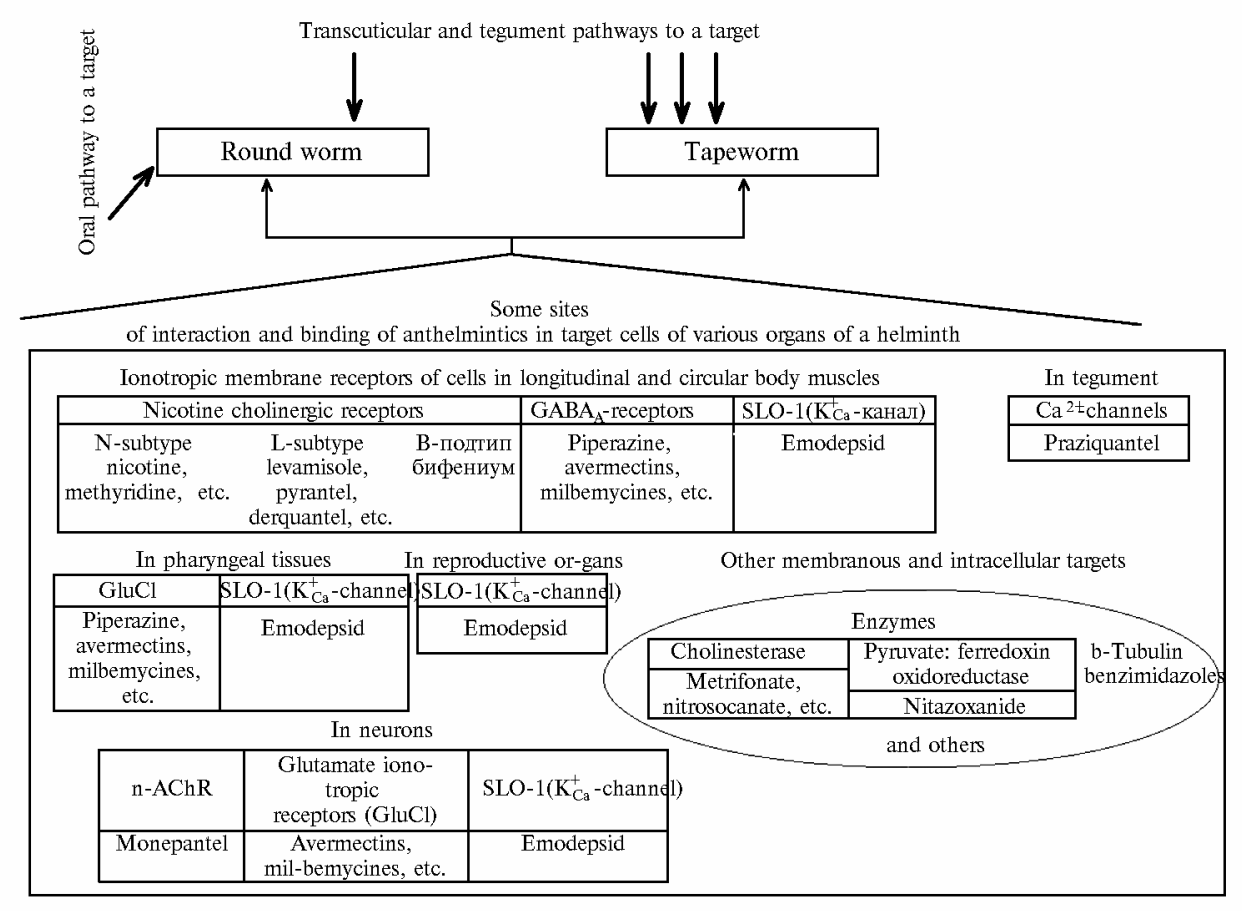

Fig. 2. Scheme of delivery of anthelmintic substances to targets (some of them; description - see in the text).

Efficiency. Cost-effectiveness of chemoprophylaxis and chemotherapy of helminthiases largely depends on accuracy and appropriateness of provided treatment with connection to effectiveness of drugs, worm's developmental cycle, host's features, climate, etc. For example, mebendazole and thiabendazole show anthelmintic action against intestinal Trichinella and are ineffective against encapsulated forms $(9,57)$.

Comparing the effectiveness of anthelmintics from different generations, it can be found that introduction of new substances was accompanied by dose decline up to a minimum in avermectin (58) (Fig. 3).

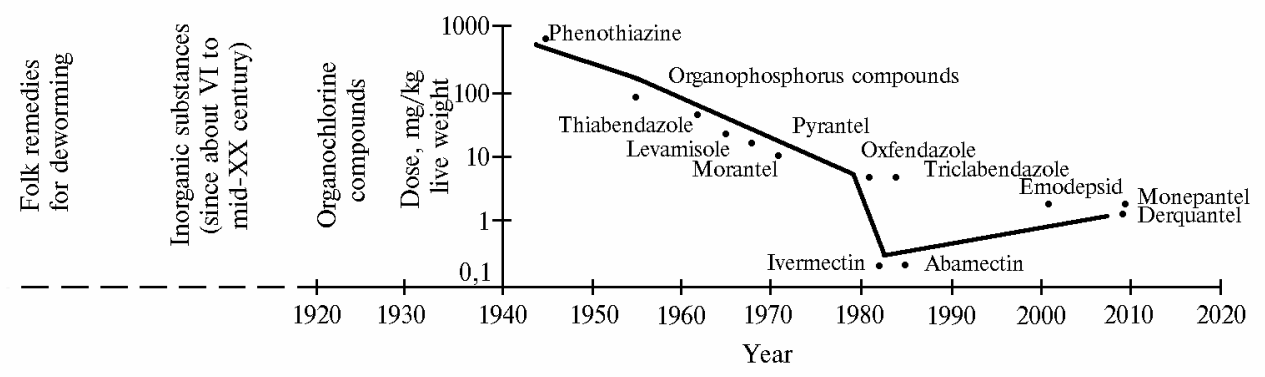

Fig. 3. Doses of various anthelmintic substances introduced in chemotherapy in different years $(45$, amended and supplemented).

Resistance to anthelmintics. Intensive chemotherapy of helminthiases may lead to undesirable biochemical consequences in a patient (negative side effects) as well as development and fixation of helminths resistant to biocidal substances. Resistance to commonly used anthelmintics was noted by P. Ehrlich at the beginning of XX century, and now it occurs quite often (59-69).

Resistance is the result of helminth's adaptation to the action of anthelmintic drug. Interaction between anthelmintic substance and a target initiates in a parasite a cascade of physicochemical and biochemical events (along with those underlying manifestation of anthelmintic activity), which affect its intracellular effectors at different levels (down to the genetic apparatus and its functional activity), after which the original target may be modified (Fig. 2). Development of resistance may be associated with reduced expression of receptor proteins in general or its subunits (nAChR agonists), increased expression of P-glycoprotein (60) and multi-resistance proteins (allosteric modulators of $\mathrm{GluCl}$ ), single nucleotide polymorphism ( $\beta$-tubulin ligands) $(56,67)$. In particular, in nematodes Caenorhabtidis elegans it was experimentally shown that simultaneous mutation of genes avr-14, avr-15, and glc- 1 encoding $\alpha$-subunit of $\mathrm{GluCl}$ causes significant resistance to ivermectin based on reduced affinity of the substance to chloride ion channel. On the contrary, mutation of any of the two genes encoding proteins involved in formation of this channel doesn't cause the resistance or it is small (68).

Helminths may also acquire drug tolerance in cases of incorrect use of anthelmintics (58-61) (Table 2).

Modern anthelmintic substances. Development of drug resistance in pathogens stimulates investigations aimed at finding new anthelmintics with an alternative mechanism of action and/or the one peculiar to existing substances though more efficient (70-72). In this regard, it should be mentioned new drugs that appeared in the market in 2000-2010 - emodepsid, monepantel, derquantel (veterinary drug), as well as tribendimidin and nitazoxanide (medicine) (Table 2).

Emodepsid is N-methyl derivative of 24-membered cyclooctadepsipeptide - a fermentation product of Mycelia sterilia that was first isolated in 1990 by Japanese scientists from leaves of Camellia japonica (74). It is effective against nematodes in the gastrointestinal tract and lungs, and against microfilaria resistant to benzimidazoles, 16-membered macrolides, and cholinergic agonists; this substance is often included in new anthelmintic drugs for cats and dogs (75-77).

Structural formulas of the substances developed in 2000-2010: 


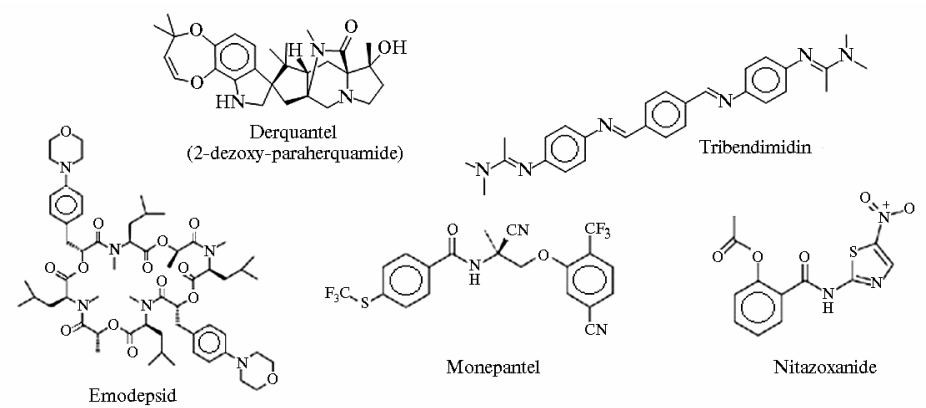

2. Some essential substances used in chemotherapy of helminthiases of man and animals

\begin{tabular}{|c|c|}
\hline Group of pathogens (pathology) & Drug, class of anthelmintics \\
\hline Intestinal nematodes & $\begin{array}{l}\quad \mathrm{N} \mathrm{e} \mathrm{m} \text { a t o d i a s i s } \\
\text { Avermectins, milbemycines, monepantel }{ }^{\text {a }} \text {, emodepsid }{ }^{\mathrm{a}} \text {, tribendimidin }{ }^{\mathrm{a}} \text {, der- } \\
\text { quantel }{ }^{\mathrm{a}} \text {, benzimidazoles, morantel, pyrantel, levamisole, closantel (and halo- } \\
\text { genated salicylanilides), piperazine }\end{array}$ \\
\hline Tissue nematodes (filariasis) & Diethylcarbamazine, suramin, ivermectin \\
\hline Tre & odiasis of different location \\
\hline Liver flukes (fasciolasis) & $\begin{array}{l}\text { Triclabendazole (against all forms), praziquantel, clorsulon, closantel (and halo- } \\
\text { genated salicylanilides), oxyclozanide, albendazole (against mature helminths) }\end{array}$ \\
\hline Blood flukes & Antimonates, metrifonate, oxamniquine, praziquantel \\
\hline Lung and intestinal flukes & $\begin{array}{l}\text { Praziquantel, triclabendazole, niclosamide (alternative), albendazole (alternative) } \\
\text { C e s t o di a s i s }\end{array}$ \\
\hline Tapeworms & Benzimidazoles, praziquantel, niclosamide \\
\hline \multicolumn{2}{|c|}{$\begin{array}{l}\text { No t e . Superscripts }\left({ }^{a}\right) \text { indicate substances established in } 2000-2010 \text {. } \\
\text { Efficiency and spectrum of action of anthelmintics depend on many factors: host species (including human), helminth } \\
\text { species (specific features of their anatomy and physiology - presence / absence of integument, temperature of a whole body and a } \\
\text { particular organ, individual differences); live cycle (bio- and geo-helminths) and associated role of a host (intermediate, final } \\
\text { host); position of a host in a food chain of ecosystem, its diet and habitat (climate, lifeway, etc.) (73, 124); bioavailability and } \\
\text { physicochemical characteristics of anthelmintic, its interaction with targets (receptors, enzymes, other metabolites and cell com- } \\
\text { ponents), etc. - all of them must be considered in prescription of efficient anthelmintic therapy. }\end{array}$} \\
\hline
\end{tabular}

Emodepsid inhibits functioning of worm's muscles in the pharynx, body, and egg-laying organs by increasing conductance of $\mathrm{Ca}^{2+}$-activated $\mathrm{K}^{+}$-channels (SLO1) in nematode's neuromuscular plexus - its presynaptic (mostly) and postsynaptic cells (78) (Fig. 4). However, the sequence of events in this case requires further clarification. It is also assumed (79) that, along with the described, this involves a minor participation of a slow-acting signaling mechanism (involving latrophilin-like receptor of presynapse and $\mathrm{G}_{\mathrm{q}}{ }^{-}$ protein) $(78,79)$.

Monepantel (S-enantiomer, a synthetic product, discovered in 2008, approved for use in 2010) is a representative of so-called amino-acetonitrile derivatives (AADs) (80). The most active metabolite is monepantel sulfone (81, 82); this substance is effective in low doses $(2.5-3.5 \mathrm{mg} / \mathrm{kg})$ against a broad spectrum of gastro-intestinal helminths in larval and adult stages resistant to conventional anthelmintics (83). Interaction of monepantel with nematode-specific nAChR Hco-MPTL-1 leads to dysfunction of this receptor which paralyzes helminth's muscles $(84,85)$. Derquantel is semisynthetic derivative of paraherquamide A isolated from natural spiroindoles - products of Penicillium paraherquei $(86,87)$. Derquantel inhibits nAChR $(88)$, it has a broad spectrum of anthelmintic actions; the mixture derquantel-abamectin is often used in treatment and control of various nematodes in the gastrointestinal tract (even ones resistant to other drugs), which allows to expect finding anthelmintic properties in similar compounds.

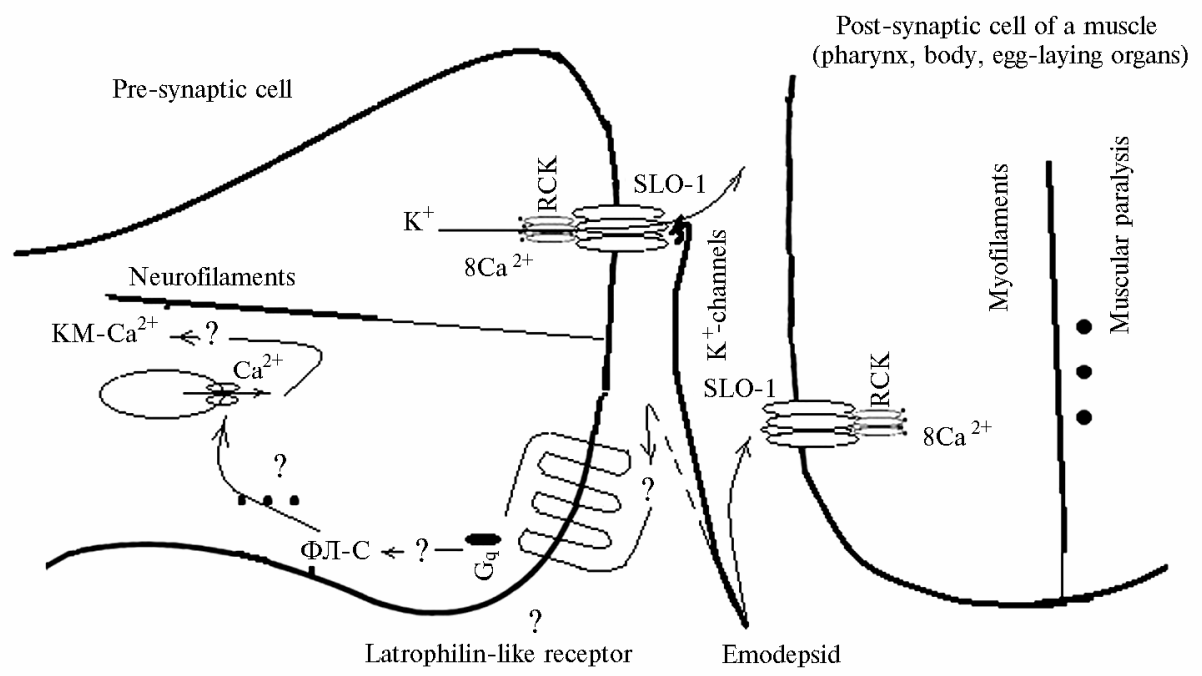

Fig. 4. Scheme of action of emodepsid: $\mathrm{KM}-\mathrm{Ca}^{2+}-\mathrm{Ca}^{2+}$-binding protein calmodulin, SLO1 $-\mathrm{Ca}^{2+}$-activated $\mathrm{K}^{+}$-channels, RCK - domain of regulated conductance of $\mathrm{K}^{+}, \mathrm{G}_{\mathrm{q}}$ - G-protein that transfers extracellular signal from membrane receptor to phospholipase C (PLC) and thus activates it (description - see in the text).

Tribendimidin is an aminophenyldimidin derivative of amidantel; it was first synthesized in China in 1980 (89) and introduced in local medical practice in 2004 (90-92). Tribendimidin is anti-nematode anthelmintic belonging to L-subtype of nAChR agonists with the mechanism of action similar to that of levamisole and pyrantel, so it is not prescribed in cases of resistance to levamisole. However, the developers suggest using tribendimidin instead of benzimidazoles or in a mixture with them in cases of 
resistance to benzimidazoles (93).

Among the recently developed anthelmintic drugs it should be noted nitazoxanide $(55,94)$ - a derivative of salicylic acid in which, unlike salicylanilides, its residue is linked via amide bond with the nitrothiazole fragment. As already mentioned, the active metabolite of nitazoxanide inhibits pyruvate: ferredoxin oxidoreductase (95). In medicine, is used as antiprotozoal, anthelmintic, and antibacterial substance (11). Nitazoxanide is less effective than benzimidazoles, but it is recommended against helminths resistant to the latter (94).

Chemical modification of known substances allows obtaining new anthelmintics, as exemplified by derivatives of benzimidazole - benzimidazolyl-chalcones (chalcones - flavonoids with disclosed pyran ring) (96), and 5-O-succinoilavermectin - AI of the market drug Gemax (97-99). A targeted search of new original anthelmintic substances is carried out since 2005 at the initiative and with direct participation of the author in collaboration with scientists from the Regional NGO Centre for Science and Engineering Problems (Moscow), K.I. Scryabin Moscow State Academy of Veterinary Medicine and Biotechnology, N.D. Zelinsky Institute of Organic Chemistry (Moscow), Yaroslavl State Technical University, Chemistry Department of M.V. Lomonosov Moscow State University, A.N. Severtsov Institute of Ecology and Evolution (Moscow). The purpose of this so-called horizontal research is creation of analogs with improved physicochemical and pharmacological properties (e.g., diminished residual content in breast milk after treatment during lactation, etc.). These derivatives of benzimidazole and avermectin have the following structural formula:

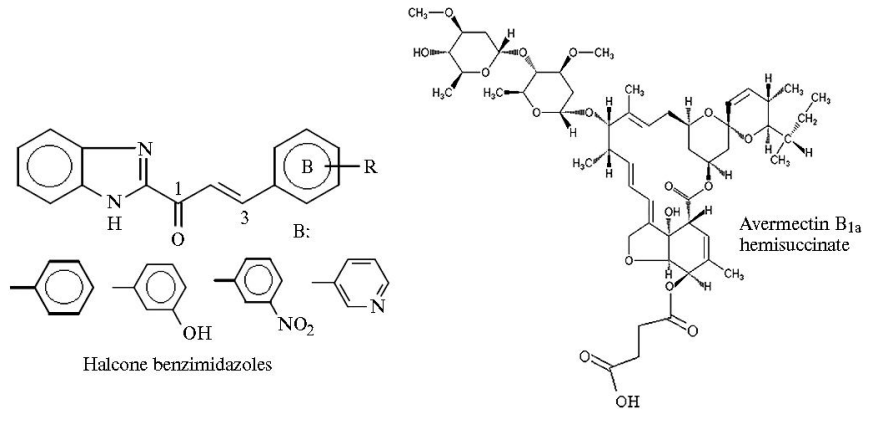

Alternative methods and prospects in control of helminthiases. There are various alternative approaches to the control of helminth infections in animals - biological treatment of pastures against helminth eggs (e.g. with nematophage fungus Duddingtonia flagrans (100), water bodies (ascomycete Caryospora callicarpa YMF1.01026) (101), and gastrointestinal tract (nematophage fungus Pochonia chlamydosporia) (102), strengthening animals' immune defenses (103), breeding species and lines resistant to helminths. Some prospects in development of vaccines based on tissues of resistant helminths have appeared since the discovery in mammalians' innate and adaptive immune system of pattern recognition receptors (PRR) capable of specific interaction with antigens of roundworms and tapeworms (104). Chemotherapy of filariasis with antibacterial agents against Wolbachia pipientis (cytoplasmic symbiont of nematodes) (105), e.g. doxycycline - antibiotic of tetracycline group (106), may be another promising method of prevention and treatment of helminthiases (107). It is worthy of note that over $90 \%$ investigated nematodes have endosymbionts $(56,108)$.

A promising direction of research is focused on synthetic anthelmintic substances in the series of conditionally parent hydrocarbons of benzene, indene, naphthalene, $1 \mathrm{H}$-cyclopenta[a]-naphthalene, and phenanthrene with structural variation from fully unsaturated to saturated forms, including heterocyclic forms containing atoms $\mathrm{N}, \mathrm{O}, \mathrm{S}$, various substituents, and functional groups. This is exemplified by well-known anthelmintics biphenyl, bifenium, the new discovered ones monepantel and tribendimidin containing respectively, two and three residues of benzene, as well as a natural compound fervenulin whose core can be presented as heterocycle similar to naphthalene whose five carbon atoms were hypothetically replaced to nitrogen (109).

Certainly, it is still important to perform screening of metabolites of terrestrial and marine organisms, mainly bacteria, fungi, plants, and, probably, venomous animals (spider toxins, toad bufotoxin with cardiotonic activity), as well as synthetic and semisynthetic analogs of such compounds. They may have different chemical nature - mono- and polycyclic (condensed and uncondensed), aromatic (e.g., polyhydric phenols - vegetable tannins), and heterocyclic (e.g., fervenulin) compounds, flavonoids, lactones, alkaloids, terpenoids, peptides, etc. Discovery of new substances with anthelmintic properties is suggested by numerous recent reports: fungichromine B (28-membered polyene macrolide product of actinomycete Streptomyces albogriseolus HA10002, effective against tuber nematode) (110), fervenulin (109), nafuredin (product of Aspergillus niger FT- 0554) (111), bacterial protein Cry5B (Bacillus thuringiensis) (112), cysteine proteases of pineapple, papaya, and some other plants (113), alkaloids of marine bryozoans (114), other substances (115).

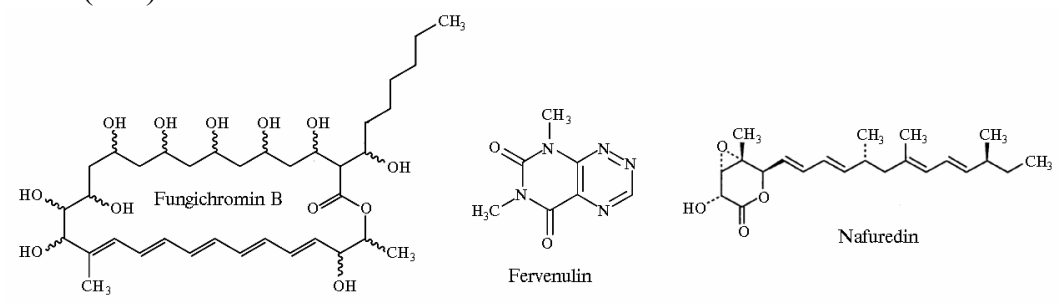

Anthelmintic properties were found in some cardiotonic steroids (natural cardenolides and bufadienolides, synthetic $14 \beta$ hydroxy derivatives of estrogens) such as asperosid from the stem bark of Streblus asper (116) and synthetic 14-methoxy-18-methylestrone (117). It is known that positive inotropic action of cardiotonic steroids is associated with inhibition of membrane Na,KATPase (118), along with the recently discovered antitumor effect (119). At the same time, it was observed modulation of activity of $\mathrm{GABA}_{\mathrm{A}}$-receptor by neurosteroids (120). Therefore, the mechanism of anthelmintic action of these substances (inhibition of Na,KATPase or some other way) needs further investigation.

Another potentially valuable group is a variety of saturated and unsaturated derivatives of cys-hydrindane, including conventional heterocyclic analogs (such as benzimidazole). This fully hydrogenated indene, CD-fragment of aglycones of cardiac steroids; divalent residue of cis-1-oksahydrinden-4,5 included in 16-membered macrolide anthelmintics; BC fragment of 1H-cyclo- 
penta[a]-naphthalene (particularly santonin containing condensed 5-membered lactone ring, see summary). In this regard, it may be found promising agents among 8,14-secosteroids (analogs of Torgov secodiketone) (121), and 9,10-secosteroids - compounds similar to vitamin $\mathrm{D}_{2}$ missing alkyl group at $\mathrm{C}$ (17) (122).

Anthelmintic action was also revealed in other classes of synthetic steroid compounds (the data will be published in respective patents).

Development of a new substance, whether it is design of a new compound or identification of certain properties in a known one is time-consuming and costly process. Applied methods of diversification (heterogeneous compounds) and focused screening (related compounds), computer evaluation of anthelmintic effects in silico (123), chemical and genetic investigations in small animal models (nematode C. elegans, etc.) must facilitate introduction of new substances (56). Deep knowledge of molecular mechanisms of anthelmintic action and drug resistance allow to improve the planning of helminth control activities.

Thus, chemotherapy is the major method of anthelmintic therapy. The development of resistance to known anthelmintic substances in worms requires constant renewal of drugs. Systematization of known substances by their chemical structure allow concluding some prospects for finding new anthelmintics among the series of derivatives of conditional parent hydrocarbons benzene, indene, naphthalene, 1H-cyclopenta[a]naphthalene, and phenanthrene, regarding their structural variation from fully unsaturated to saturated forms and including heterocyclic analogs containing nitrogen, oxygen, sulfur, various substituents, and functional groups.

\section{REFERENCES}

1. Krasnopol'skaya I. Rossiiskaya gazeta, № 3359, 03.12.2003.

2. Marushko Yu.V., Gracheva M.G. Sovremennaya pediatriya, 2012, 3(43): 21-26.

3. Díez-Morrondo C., Sánchez-Andrade R., Ibaseta P., Suárez J.L., Francisco I. et al. A case-control study to analyze the influence of the environment in human sensitization against helminth parasitic antigens. Rev. Ibero-Latinoam. Parasitol., 2010, 69(1): 38-44.

4. Biryukov S.A., Lemekhov P.A. Molochnokhozyaistvennyi vestnik, 2011, 3: 14-16.

5. Integrated management of fruit crops and forest nematodes /E.A. Ciancio, K.G. Mukerji (eds.). Springer, 2009; ISBN 978-1-4020-6062-5

6. Kryuchkova E.H., Petrov Yu.F., Shakhbiev Kh.Kh. Veterinariya Kubani, 2011, 5: 7-8.

7. Karsakov N.T., Ataev A.M., Zubairova M.M., Nasirkhanova Z.Sh. Rossiiskii parazitologicheskii zhurnal, 2008 , $3:$ 56-59.

8. Fataliev G.G., Elchuev M.Sh., Ibragimova R.Sh. Vlivanie mestoobitaniya na gel'mintofaunu dikikh i domashnikh plotoyadnykh zhivotnykh yuzhnogo sklona

Bol'shogo Kavkaza(http://www.rusnauka.com/3 ANR 2013/Biologia/6 126906.doc.htm).

9. Goodman and Gilman's the pharmacological basis of therapeutics. 12th ed./L. Brunton, B. Chabner, B. Knollman (eds.). McGraw-Hill, 2011 , ISBN 0071624422.

10. Arkhipov I.A. Antgel'mintiki: farmakologiya i primenenie [Anthelmintics: Pharmacology and Treatment]. Moscow, 2009.

11. Plumb D.C. Plumb's veterinary drug handbook. 6th ed. Verlag/Jahr, Wiley \& Sons, 2008, ISBN 978-0-8138-1097-3.

12. Antiparasitic and antibacterial drug discovery/P.M. Selzer (ed.). Wiley-VCH, 2009, ISBN 978-3-527-32327-2.

13. Mirskii M.B. Proc. of The First International conference «Traditional medicine and materia medica in medieval manuscripts»/F. Alakbarli (ed.). Baku, 2006

(http://aamh.az/index.files/13.htm)

14. Encyclopedia of parasitology. 3rd ed. /H. Mehlhorn (ed.). Springer, 2008.

15. Alakbarli F. Medica manuscripts of Azerbaijan. Baku, HAF, 2006: 3 (http://www.alakba-rli.aamh.az/index files/57.htm).

16. Proc. of The First International conference «Traditional medicine and materia medica in medieval manuscripts» (June 12-14, 2006, Baku, Azerbaijan) /F. Alak-

barli (ed.). UNESCO, Paris/Baku, 2006 (http://aamh.az/index.files/13.htm).

17. Gippokrat. Sochineniya. Kniga 1. Perevod V.I. Rudneva, kommentarii V.P. Karpova [Works, Vol. 1]. Moscow, 1994.

18. Blinova K.F., Yakovlev G.P. Botaniko-farmakognosticheskii slovar' [Dictionary of Botanical and Pharmacological Terms]. Moscow, 1990, ISBN 5-06-000085-0.

19. Ibn Sina. Kanony vrachebnoi nauki. Tom 1-5 [The Canon of Medicine. Vol. 1-5]. Tashkent, 1956-1960 (http://www.erlib.com).

20. Greenwood D. Antimicrobial drugs: chronicle of a twentieth century medical triumph. N.-Y., Oxford University Press Inc., $2008: 30$.

21. Entsiklopedicheskii slovar' F.A. Brokgauza i I.A. Efrona [Brokhaus and Efron Encyclopedic Dictionary] (http://www.vehi.net/brokgauz/).

22. Woodward R.B., Yates P. The structure of the $a$ - and b-metasantonins. J. Am. Chem. Soc., 1963, 85(5): 553-557.

23. K'yusev I.A. Polnyi spravochnik lekarstvennykh rastenii [A Complete Guide to Medicinal Plants]. Moscow, 2005.

24. Lloyd J.U., Lloyd C.G. History of the vegetable drugs of the U.S.P. Cincinnati, 1911 (http://www.swsbm.com/ManualsOther/USP_Drug_History_Lloyd.pdf).

25. Belikov V.G. Farmatsevticheskaya khimiya. 3-e izdanie [Pharmaceutical Chemistry]. Moscow, 2009: 20-33.

26. Mashkovskii M.D. Lekarstvennye sredstva: Posibie dlya vrachei. Tom 1 [Medicinal Preparations: Doctor's Manual. Vol. 1]. Moscow, 2004: 334.

27. Rabota po likvidatsii global'nykh posledstvii «zabytykh» tropicheskikh boleznei. Pervyi doklad VOZ po «zabytym» tropicheskim boleznyam. [The First WHO Report on Neglected Tropical Diseases: Working to Overcome the Global Impact of Neglected Tropical Diseases] WHO/HTM/NTD, $2010,2: 15$.

28. Riethmiller S. Erlich, Bertheim, and atoxyl: the origins of modern chemotherapy. Bull. Hist. Chem., 1999, 23(1): 28-33.

29. Ozeretskovskaya N.N. Human opisthorchiasis in the USSR.http://whqlibdoc.who.int/hq/pre-wholis/INT.PAR.SG_INF_80.7.pdf

30. Akramovskii M.N., Egorova Yu.G., Bashkirtseva E.V. Veterinariya, 1957, 4: 43-44.

31. Arabkhanov B.G. Materialy nauchnoi konferentsii VOG [Proc. Sci. Conference of the All-Union Society of Helminthologists]. Moscow, 1974, v. 26: 15-20

32. Rawlings C.A., McCall J.W. Melarsomine: A new heartworm adulticide.Compendium on continuing education for the practicing veterinarian, $1996,18: 373-379$.

33. Zhorobekova Sh.Zh., Toimbetov M.T., Aimukhamedova M.B. et al. Pektinat al'bendazola i medi (II), obladayushchii antigel'mintnoi aktivnost'yu. Patent C 08 C

37/06; A 61 K 31/70. Opubl. 29.02.2008. Byul. № 2 (KG) [Pectinate of Albendazole and Copper (II) with Anthelmintic Effect, RU Patent 1 C 08 C 37/06; A 61 K

31/70, Pub. 29.02.2008, Bull. № 2 (KG)].

34. Swales W.E. Tests of phenothiazine as anthelmintic. Can. J. Comp. Med., 1939, 3(7): 188-194.

35. Davies M.T., Forrest J., Hartley F., Petrow V. Piperazine adipate: a new anthelmintic agent. J. Pharm. Pharmacol., 1954, 6(1): 707-710.

36. Campbell W.C. Benzimidazoles: veterinary uses. Parasitology Today, 1990, 6(4): 130-133.

37. Thienpont D., Vanparijs O.F.J., Raeymaekers A.H.M. et al. A new, potent broad spectrum anthelmintic tetramisole. Nature, $1966,209: 1084-1086$.

38. Austin W.C., Courtney W., Danilewicz J.C. et al. Pyrantel tartrate, a new anthelmintic effective against infections of domestic animals. Nature, 1966, 212(6): 1273-

1274 .

39. Seubert J., Pohlke R., Loebich F. Synthesis and properties of praziquantel, a novel broad spectrum anthelmintic with excellent activity against schistosomes and cestodes. Experientia, 1977, 33: 1036-1037.

40. Campbell W.C. History of avermectin and ivermectin, with notes on the history of other macrocyclic lactone antiparasitic agents. Curr. Pharm. Biotechnol., 2012, 13(6): 853-865.

41. Macrolide antibiotics. Chemistry, biology and practice. 2nd ed. /S. Omura (ed.). N.Y., Elsevier Sci., 2002.

42. Omura S. Ivermectin: 25 years and still going strong. Int. J. of Antimicrob. Agents, 2008, 31(2): 91-98.

43. Crump A., Omura S. Ivermectin, «Wonder drug» from Japan: the human use perspective. Proc. Jpn. Acad., Ser., 2011, B 87(2): 13-28.

44. Mrozik H., Eskola Ph., Arison P. et al. 2-Deoxy-4"-aminoavermectins with potent broad spectrum antiparasitic activities. Bioorg. Med. Chem. Lett., 1995, 5: 24352440 .

45. Pitterna T., Cassayre J., Huter O. et al. New ventures in the chemistry of avermectins. Bioorg. Med. Chem., 2009, 17: 4085-4095.

46. Zavarzin I.V., Dzhafarov M.Kh., Kolobov A.V., Chernoburova E.I., Bobova T.A. 5-O-Proizvodnye avermektina, sposob ikh polucheniya i antiparazitarnye sredstva na ikh osnove. Patent RF № 2472801. Prioritet 11.05.2011. Opubl. 20.01.2013. Byul. № 2 [Method for Their Production and the Antiparasitic Drugs, RU Patent № 2472801, Priority 11.05.2011, Pub. 20.01.2013., Bull. № 2.].

47. Lynagh T., Lynch J.W. Molecular mechanisms of Cys-loop ion channel receptor modulation by ivermectin. Front. Mol. Neurosci., 2012, 5(article 60): 1-11.

48. Hashimoto H., Messerli S. M., Sudo T., Maruta H. Ivermectin inactivates the kinase PAK1 and blocks the PAK1-dependent growth of human ovarian cancer and NF2 tumor cell lines. Drug Discov. Ther., 2009, 3(6): 243-246.

49. Mosin V.A., Drinyaev V.A., Kokoz Yu.M et al. Sredstvo, usilivayushchee protivoopukholevuyu aktivnost' khimiopreparatov, i sposob lecheniya onkologicheskikh zabolevanii. Patent RF № 2250775. Opubl. 27.04.2005 [The Preparation Enhancing Anti-Cancer Activity of Chemotherapeutic Drugs, and the Treatment Method, RU Patent № 2250775, Pub. 27.04.2005].

50. Mastrangelo E., Pezzullo M., De Burghgraeve T., Kaptein S., Pastorino B., Dallmeier K., De Lamballerie X., Neyts J., Hanson A.M., Frick D.N., Bolognesi M., 
Milani M. Ivermectin is a potent inhibitor of flavivirus replication specifically targeting NS3 helicase activity: new prospects for an old drug. J. Antimicrob. Chemother., 2012, 67(8): 1884-1894.

51. Kobylinski K.C., Foy B.D., Richardson J.H. Ivermectin inhibits the sporogony of Plasmodium falciparum in Anopheles gambiae. Malaria Journal, 2012, 11: 381 52. Lim L.E., Vilchèze C., Ng C., Jacobs W.R. Jr., Ramon-García S., Thompson C.J. Anthelmintic avermectins kill Mycobacterium tuberculosis, including multidrug resistant clinical strains. Antimicrob. Agents Chemother., 2013, 57(2): 1040-6.

53. Approaches to design and synthesis of antiparasitic drugs/S. Sharma, N. Anand (eds.). Elsevier, 1997: $239-257$.

54. Griffin S.A., Chamberlain C.C. Value of hygromycin B as an antibiotic and as an anthelmintic for swine. J. Animal Sci., 959(18): 1161-6.

55. Speich B., Ame S.M., Ali S.M., Alles R., Hattendorf J., Utzinger J., Albonico M., Keiser J. Efficacy and safety of Nitazoxanide, Albendazole, and NitazoxanideAlbendazole against Trichuris trichiura infection: A randomized controlled trial. PLoS Negl. Trop. Diseas, 2012, 6(6): e1685.

56. Parasitic helminths. Targets, screens, drugs and vaccines /C.R. Caffrey (ed.). Wiley-VCH, 2012, ISBN 978-3-527-33059-1.

57. Martin R.J. Modes of action of anthelmintic drugs. Vet. J., 1997, 154: 11-34.

58. Waller P.J. From discovery to development: current industry perspectives for development of novel methods of helminth control in livestock. Vet.

Parasitol., 2006, 139(1): 1-14.

59. Prichard R.K. Ivermectin resistance and overview of the consortium for anthelmintic resistance SNPs. Expert Opin. Drug Discov., $2007,2: 41-52$.

60. Bourguinat C., Keller K., Blagburnb B., Schenker R., Geary T.G., Prichard R.K. Correlation between loss of efficacy of macrocyclic lactone heartworm anthelmintics and P-glycoprotein genotype. Vet. Parasitol., 2011, 176: 374-381.

61. European strategic action plan on antibiotic resistance. Reg. Com. for Europe. 61st session. Baku, 2011

(http://www.euro.who.int/ data/assets/pdf file/0008/147734/wd14E AntibioticResistance 111380.pdf).

62. Geerts S., Gryseels B. Drug resistance in human helminths: Current situation and lessons from livestock. Clinic. Microb. Rev., $2000,13(2)$ : $207-222$.

63. Beech R.N., Skuce P., Bartley D.J., Martin R.J., Prichard R.K., Gilleard J.S. Anthelmintic resistance: markers for resistance, or susceptibility. Parasitology, 2011,

138(2): 160-174.

64. Torres-Acosta J.F., Mendoza de Gives P., Aguilar-Caballero A.J., Cuellar-Ordaz J.A. Anthelmintic resistance in sheep farms: update of the situation in the American continent. Vet. Parasitol., 2012, 189(1): 89-96.

65. Gasbarre L.C., Smith L.L., Lichtenfels J.R., Pilitt P.A. The identification of cattle nematode parasites resistant to multiple classes of anthelmintics in a commercial cattle population in the US. Vet. Parasitol., 2009, 166: 281-285.

66. Good B., Hanrahan J.P., Theodorus de Waal D., Patten T., Kinsella A., Lynch C.O. Anthelmintic-resistant nematodes in Irish commercial sheep flocks - the state of play. Irish Vet. J., 2012, 65(1): 1-5.

67. Holden-Dye L., Walker R.J. Anthelmintic drugs. WormBook, 2007 (http://www.wormbook.org).

68. Dent J.A. Smith Mc.M. Vassilatis D.K. Avery L. The genetics of ivermectin resistance in Caenorhabditis elegans. PNAS USA, 2000, 97(6): 2674-2679.

69. Jovanovic S., Savic M., Zivkovic D. Genetic variation in disease resistance among farm animals. Biotechnology in Animal Husbandry, 2009 , 25(5-6): 339-347.

70. Von Samson-Himmelstjerna G., Prichard R.K., Wolstenholme A.J. Anthelmintic resistance as a guide to the discovery of new drugs? In: Antiparasitic and antibacterial drug discovery: from molecular targets to drug candidates/P.M. Selzer (ed.). WILEY-VCH Verlag GmbH \& Co. KGaA, Weinheim, 2009, ISBN 978-3-527-

32327-2: 17-32.

71. Elsheikha H., Rauch C. Redefining the limits of biochemistry in multidrug resistant nematodes: Implications for future drug development. J. Vet. Sci. Technol.,

2012, 3: 6 .

72. Patil P.N. Discoveries in pharmacological sciences. World Scientific Pub. Co., Inc., 2012, ISBN 9814355070.

73. Reynecke D.P., Waghorn T.S., Oliver A.M., Miller C.M., Vlassoff A., Leathwick D.M. Dynamics of the free-living stages of sheep intestinal parasites on pasture in the North Island of New Zealand. 2. Weather variables associated with development. N.-Z. Vet. J., 2011, 59(6): 287-92.

74. Harder A., Von Samson-Himmelstjerna G. Cyclooctadepsipepides — a new class of anthelmintically active compounds. Parasitol. Res., 2002 , 88(6): 481-488.

75. Bakh T., Tentsler Ya. Predotvrashchenie vertikal'nykh infektsii, vyzyvaemykh endoparazitami. Patent RF № 2405565. Opubl. 2010. Byul. № 34[Preventing Vertical Endoparasite Infections, RU Patent 2405565, Pub. 2010, Bull. № 34]

76. Arkhipov I.A., Zubov A.V., Abramov V.E., Tikhanova N.V. Rasprostranenie gel'mintozov koshek v Rossii i ikh terapiya s primeneniem antigel'mintnogo lekarstvennogo sredstva Profender ${ }^{\circledR}$ proizvodstva firmy «Vaueg HealthSare AG», Germaniya. Mat. II Sochinskogo veterinarnogo festivalya [Proc. II Sochi Veterinarian Festival]. Sochi, 2007: 6-11.

77. Krudewagen E.M., Schimmel A. Concomitant simultaneous and consecutive treatment of imidacloprid/moxidectin spot-on with emodepside/praziquantel tablets in adult dogs. Intern. J. Appl. Res. Vet. Med., 2011, 9(3): 290-299.

78. Holden-Dye L., Crisford A., Welz C., Von Samson-Himmelstjerna G., Walker R.J., O'Connor V. Worms take to the slo lane: a perspective on the mode of action of emodepside. Invert. Neurosci., 2012, 12: 29-36.

79. Martin R.J., Buxton S.K., Neveu C., Charvet C.L., Robertson A.P. Emodepside and SLO-1 potassium channels: A review. Exper. Parasitol., 2012, 132(1): 40-46.

80. Kaminsky R., Ducray P., Jung M. et al. A new class of anthelmintics effective against drug-resistant nematodes. Nature, 2008, 452: 176-180.

81. Karadzovska D., Seewald W., Browning A., Smal M., Bouvier J., Giraudel J.M. Pharmacokinetics of monepantel and its sulfone metabolite, monepantel sulfone, after intravenous and oral administration in sheep. J. Vet. Pharmacol. Ther., 2009, 32(4): 359-367.

82. Stuchlíková L., Jirásko R., Vokrál I., Lamka J., Špulák M., Holcapek M., Szotáková B., Bártíková H., Pour M., Skálová L. Investigation of the metabolism of monepantel in ovine hepatocytes by UHPLC/MS/MS. Analyt. Bioanalyt. Chem., 2013, 405(5): 1705-1712.

83. Baker K.E., George S.D., Stein P.A. et al. Efficacy of monepantel and anthelmintic combinations against multiple-resistant Haemonchus contortus in sheep, including characterisation of the nematode isolate. Vet. Parasitol., 2012, 186: 513-517.

84. Epe C., Kaminsky R. New advancement in anthelmintic drugs in veterinary medicine. Trends. Parasitol., 2013, 29(3): 129-134;

85. Rufener L., Baur R., Kaminsky R., Mäser P., Sigel E. Monepantel allosterically activates DEG-3/DES-2 channels of the gastrointestinal nematode Haemonchus contortus. Mol. Pharm., 2010, 78(5): 895-902.

86. Little P.R., Hodges A., Maeder S.J., Wirtherle N.C., Nicholas D.R., Cox G.G., Conder G.A. Efficacy of a combination oral formulation of derquantel-abamectin against the adult and larval stages of nematodes in sheep, including anthelmintic-resistant strains. Vet. Parasitol., 2011, 181(2-4): 180-193.

87. Finefield J.M., Frisvad J.C., Sherman D.H., Williams R.M. Fungal origins of the bicyclo[2.2.2]diazaoctane ring system of prenylated indole alkaloids. J. Nat. Prod., 2012, 75(4): 812-833.

88. Kaminsky R., Bapst B., Stein P.A. et al. Differences in efficacy of monepantel, derquantel and abamectin against multi-resistant nematodes in sheep. Parasitol. Res., 2011, 109: 19-23.

89. Xiao S.H., Hui-Ming W., Tanner M., Utzinger J., Chong W. Tribendimidine: a promising, safe and broad-spectrum anthelmintic agent from China. Acta Trop., 2005, 94(1): $1-14$.

90. Keiser J., Shu-Hua X., Chollet J., Tanner M., Utzinger J. Evaluation of the in vivo activity of Tribendimidine against Schistosoma mansoni, Fasciola hepatica,Clonorchis sinensis, and Opisthorchis viverrini. Antimicrob. Agents Chemother., 2007, 51(3): 1096-1098.

91. Keiser J., Thiemann K., Endriss Y., Utzinger J. Strongyloides ratti: in vitro and in vivo activity of tribendimidine. PLoS Negl. Trop. Diseas., 2008, 2(1): e136. 92. Yuan G., Xu J., Qu T., Wang B., Zhang R., Wei C., Guo R. Metabolism and disposition of tribendimidine and its metabolites in healthy Chinese volunteers.Drugs R. D., 2010, 10(2): 83-90.

93. Hu Y., Xiao S.-H., Aroian R.V. The new anthelmintic tribendimidine is an L-type (levamisole and pyrantel) nicotinic acetylcholine receptor agonist. PLoS Negl. Trop. Diseas., 2009, 3(8): el499.

94. Broekhuysen J., Stockis A., Lins R.L., De Graeve J., Rossignol J.F. Nitazoxanide pharmacokinetics and metabolism in man. Int. J. Clin. Pharmacol. Ther., 2000, 38: $387-394$.

95. Halsey J.L. Current approaches to the treatment of gastrointestinal infections: focus on nitazoxanide. Clinical Medicine: Therapeutics, 2009, 1: 263-275.

96. Ouattara M., Sissouma D., Kone M.W., Menan H.E., Toure S.A., Ouattara L. Synthsesis and anthelmintic activity of some hybrid benzimidazolyl-chalcone derivatives. Trop. J. Pharm. Res., 2011, 6(6): 767-775

97. Dzhafarov M.Kh., Mirzaev M.N., Urazaev D.N., Maksimov V.I. Antiparasitic activity of adermectin and compounds of a steroid nature. Russian Agricultural Sciences, 2010, 36, 2: 130-132.

98. Dzhafarov M.Kh., Zavarzin I.V., Mirzaev M.N. Devrishova Z.A., Yusupov Yu.A. Effektivnost' preparata gemaks pri strongilyatozakh ovets.

Sel'skokhozyaistvennaya Biologiya [Agricultural Biology], 2012, 2: 96-101.

99. Zavarzin I.V., Dzhafarov M.Kh., Kolobov A.V., Chernoburova E.I., Bobova T.A. 5-O-Proizvodnye avermektina, sposob ikh polucheniya i antiparazitarnye sredstva na ikh osnove. Patent RF № 2472801. Prioritet 11.05.2011. Opubl. 20.01.2013. Byul. № 2 [Avermectin 5-O-Derivatives, Method for Their Production and the Antiparasitic Drugs, RU Patent № 2472801, Priority 11.05.2011, Pub. 20.01.2013., Bull. № 2.].

100. Luk'yanchenko T.A. Vestnik zoologii, 2000, 34(3): 67-72.

101. Dong J., Zhu Y., Song H., Li R., He H., Liu H., Huang R., Zhou Y., Wang L., Cao Y., Zhang K. Nematicidal resorcylides from the aquatic fungus Caryospora callicarpa YMF1.01026. J. Chem. Ecol., 2007, 33: 1115-1126. 
102. Dias A.S., Araujo J.V, Braga F.R. et al. Biological control of Fasciola hepatica eggs with the Pochonia chlamydosporia fungus after passing through the cattle gastrointestinal tract. Parasitol. Res., 2012, 110(2): 663-667.

103. Reynolds L.A., Filbey K.J., Maizels R.M. Immunity to the model intestinal helminth parasite Heligmosomoides polygyrus. Semin. Immunopathol., 2012, 34: 829846.

104. Lebedev K.A., Ponyakina I.D. Immunologiya obrazraspoznayushchikh retseptorov (integral'naya immunologiya) [Integral Immunology of Image-Recognizing Receptors]. Moscow, 2009: 112.

105. Werren J.H., Baldo L., Clark M.E. Wolbachia: master manipulators of invertebrate biology. Nature Rev. Microbiol., 2008,6 : 741-751.

106. Hoerauf A., Specht S., Büttner M., Pfarr K., Mand S., Fimmers R., Marfo-Debrekyei Y., Konadu P., Debrah A.Y., Bandi C., Brattig N. et al. Wolbachia endobacteria depletion by doxycycline as antifilarial therapy has macrofilaricidal activity in onchocerciasis: a randomized placebo-controlled study. Med. Microbiol. Immunol., 2008, 197: 295-311.

107. Johnston K.L., Wu B., Guimaraes A., Ford L., Slatko B.E., Taylor M.J. Lipoprotein biosynthesis as a target for anti-Wolbachia treatment of filarial nematodes. Parasit. Vect., 2010, 3: 99.

108. McGraw E.A., O’Neill S.L. Beyond insecticides: new thinking on an ancient problem. Nature Rev. Microbiol., 2013, 11: 181-193.

109. Ruanpanun P., Laatsch H., Tangchitsomkid N., Lumyong S. Nematicidal activity of fervenulin isolated from a nematicidal actinomycete, Streptomycessp. CMUMH021, on Meloidogyne incognita. World J. Microbiol. Biotechnol., 2011, 27: 1373-1380.

110. Zeng Q., Huang H., Zhu J., Fang Z., Sun Q., Bao S. A new nematicidal compound produced by S. albogriseolus HA10002. Springer, 2013

(http://www.ncbi.nlm.nih.gov/pubmed/23444037).

111. Hrckova G., Velebny S. Pharmacological potential of selected natural compounds in the control of parasitic diseases. SpringerBriefs, 2013, ISBN 978-3-70911324-0: 29-99.

112. Hu Y., Zhan B., Keegan B., Yiu Y.Y., Miller M.M., Jones K., Aroian R.V. Mechanistic and single-dose in vivo therapeutic studies of Cry5B anthelmintic action against hookworms. PLoS NTD, 2012, 6(11): e1900.

113. Behnke J.M., Buttle D.J., Stepek G., Lowe A., Duce I.R. Developing novel anthelmintics from plant cysteine proteinases. Parasit. Vect., 2008, 1: 1-28.

114. Narkowics C.K., Blackman A.J., Lacey E. et al. Convolutindole A and convolutamine H, new nematicidal brominated alkaloids from the marine bryozoan Amantha convoluta. J. Nat. Prod., 2002, 65: 938-941.

115. Tandon V., Yadav A. K., Roy B., Das B. Phytochemicals as cure of worm infections in traditional medicine systems. Emerging Trends in Zoology, 2011: 351378.

116. Chatterjee R.K., Fatma N., Murthy P.K., Sinha P., Kulshreshtha D.K., Dhawan B.N. Macrofilaricidal activity of the stem bark of Streblus asper and its major active constituents. Drug Dev. Res., 1992, 26: 67-78.

117. Dzhafarov M.KH., Mirzaeva K.M., Zavarzin I.V., Devrishova Z.A., Mirzaev M.N. Zhurnal veterinarnoi meditsiny, 2012, 1: 37-39.

118. Schatzmann H.J., Rass B. Inhibition of the active Na,K-transport Na,K-activated membrane ATPase of erythrocyte stroma by ouabain. Helv. Physiol. Pharmacol. Acta, 1965, 65(1): 47-49.

119. Prassas I., Diamandis E.P. Novel therapeutic applications of cardiac glycosides. Nature Rev., 2008, 7: $926-935$.

120. Li G.-D., Chiara D.C., Cohen J.B., Olsen R.W. Neurosteroids allosterically modulate binding of the anesthetic etomidate to g-aminobutyric acid type A receptors. J. Biol. Chem., 2009, 284(18): 11771-11775.

121. Dhzafarov M.Kh. Retroaldol processes in steroid chemistry. Russ. Chem. Reviews, 1992, 61(3): 363-372.

122. Dzhafarov M.Kh., Maksimov V.I. Steroidy. Stroenie, poluchenie, svoistva i biologicheskoe znachenie. Primenenie v meditsine i veterinarii [Steroids: Structure, Production, Properties, and Biological Significance, Applications in Medicine and Veterinary]. St. Petersburg, 2010.

123. Ibarra-Velarde F., Vera-Montenegro Y., Huesca-Guillen A. et al. In silico fasciolicide activity of three experimental compounds in sheep. Ann. N.Y. Acad. Sci., 2008, 1149: 183-185.

124. Sargison N.D. Pharmaceutical treatments of gastrointestinal nematode infections of sheep — Future of anthelmintic drugs. Vet. Parasitol., 2012 , 189: 79-84. 